KATARZYNA WOŁEK-SAN SEBASTIAN

Uniwersytet Jagielloński w Krakowie

e-mail: katarzyna.wolek@uj.edu.pl

\title{
Czy istnieje polsko-chorwacka szkoła przekładu literackiego?
}

\author{
Abstract \\ Does School of Polish-Croatian Literary Translation Exist?
}

The article presents an attempt to answer the question whether Polish-Croatian translation school can be discussed within the framework of literary translation. Features of the potentially existing school are discussed, namely, the conditions of formation and functioning, chronological and geographical scope, accomplishments in the area of translation and translation studies, as well as the impact on the contemporary translation practice and teaching translation. There are several arguments in favour of the existence of the Polish-Croatian translation school. For example translators from $60 \mathrm{~s}$ and $70 \mathrm{~s}$ used a specific strategy for translating culturally marked elements (terms specific for a given culture, that are not present in the other) defined here as didactical source-orientation. Although neither their traductological discourse nor the ideal of a translator-popularizer (meaning that they weren't only translators but also authors of guides, organisers of cultural events, etc.) differs broadly enough from the Polish equivalents to advocate distinctiveness of those translation schools.

Keywords: Croatian-Polish translation, translation school, foreignization, literary translation.

Słowa kluczowe: chorwacko-polski przekład, szkoła przekładu, egzotyzacja, przekład literacki.

Nie sposób wyobrazić sobie polsko-chorwackiej interakcji kulturowej bez translacji literackiej. Twórczość przekładowa z języka chorwackiego na język polski ma na tyle długą i bogatą tradycję, że musi pojawić się pytanie o zasady i prawidłowości występujące w jej obrębie. A jeśli takie prawidłowości istnieją, to czy można mówić o swego rodzaju szkole przekładu literackiego?

Chcąc posłużyć się ściślejszą definicją szkoły przekładowej i wyjść poza intuicyjne przekonanie o jej istnieniu, musimy posłużyć się zmodyfikowaną definicją szkoły artystycznej/naukowej, której niezbywalne elementy wyodrębnił Jan Woleński w monografii Filozoficzna szkoła lwowsko-warszawska. Na obraz formacji intelektualnej składają się według Woleńskiego cztery czynniki: genetyczny, geograficzny, czasowy oraz merytoryczny ${ }^{1}$. Zatem aby zespół stosowanych technik

\footnotetext{
1 Zob. J. Woleński, Filozoficzna szkoła lwowsko-warszawska, Warszawa 1985, s. 9.
} 
i towarzyszących im przekonań w danej dziedzinie nauki lub sztuki móc uznać za coś więcej niż grupujące się tendencje, niezbędne jest nie tylko udowodnienie wspólnej genealogii i ciągłości trwania, ale również wskazanie jedności poglądów metodologicznych i merytorycznych oraz świadomości przynależności, która cechowałaby członków szkoły².

$\mathrm{Na}$ interesującym nas obszarze przekładu literackiego prześledzimy podstawowe czynniki konstytuujące potencjalną wspólnotę intelektualną thumaczy literatury chorwackiej oraz zastanowimy się, czy składają się one na jej kompletny obraz.

\section{Genealogia}

Szukając genealogicznych fundamentów „szkoły przekładowej” w literaturze chorwackiej tłumaczonej na język polski, niewątpliwie należałoby zwrócić uwagę na działalność grupy tłumaczy, krytyków, popularyzatorów i badaczy kultury chorwackiej (jugosłowiańskiej) aktywnych w latach 60. i 70. Byli to: Zygmunt Stoberski, Alija Dukanović, Halina Kalita, Maria Krukowska, Jan Wierzbicki, Danuta Cirlić-Straszyńska, Grzegorz Łatuszyński, Bożena Nowak ${ }^{3}$. Nie bez przyczyny nazywani są oni przez Leszka Małczaka „ekspertami”" oraz „pośrednikami”" łączyli kilka funkcji i nierzadko przyjmowali rolę autorytetów w kilku dziedzinach jugosłowianistycznych. Między innymi thumaczka Maria Krukowska była autorką jedynego podręcznika dla Polaków Govorite li srpskohrvatski? oraz popularnego przewodnika Jugosławia 6 . Z kolei Jan Wierzbicki uzupełnił swoją pracę przekładową i krytyczną współautorstwem podstawowego i wielokrotnie wznawianego słowniczka serbskochorwacko-polskiego i polsko-serbskochorwackiego ${ }^{7}$.

\section{Czynnik czasu i miejsca trwania}

Tłumaczenia z literatury chorwackiej, w których zauważalna byłaby spójność tendencji przekładowych, powstawały od początku lat 60 . do połowy 80 . Ich twórcy wywodzili się wówczas głównie ze środowiska warszawskiego ${ }^{8}$, co związane było z ówczesnym scentralizowanym modelem kierowania i finansowania kultury ${ }^{9}$, ale także z instytucją dydaktyczną - warszawską neofilologią. Przekłady z literatury jugosłowiańskiej pojawiały się w seriach „Współczesna Proza Światowa” (PIW) i „Nike” (Czytelnik), a dopiero nieco później w wydawanej od roku 1970 przez

\footnotetext{
${ }^{2}$ Ibid., s. 309-312.

${ }^{3}$ Periodyzacja za: L. Małczak, Croatica. Literatura i kultura chorwacka w Polsce 1944-1989, Katowice 2013.

${ }^{4}$ Ibid., s. 391.

5 Ibid., s. 60.

${ }^{6}$ M. Krukowska, Govorite li srpskohrvatski? Zwięzly kurs języka serbochorwackiego, Warszawa 1971; eadem, Jugostawia, Warszawa 1967.

7 J. Wierzbicki, U. Radnović, J. Chlabicz, Mały stownik serbskochorwacko-polski, polsko-serbskochorwacki, Warszawa 1966.

${ }^{8}$ L. Małczak, op. cit., s. 54.

${ }^{9}$ Ibid., s. 285-298.
} 
Wydawnictwo Łódzkie serii „Biblioteka Jugosłowiańska”. Tłumacze jugosłowianiści należeli do zespołów redakcyjnych czasopism „Literatura na Świecie”, „Twórczość”, „Rocznik Literacki”, współpracowali z nimi jako krytycy i tam też publikowali swoje przekłady. Nowości przekładowe omawiano przede wszystkim w „Nowych Książkach”, a recenzje te (w formie całorocznego przeglądu) wychodziły spod pióra osób, które same były praktykującymi tłumaczami ${ }^{10}$.

\section{Czynnik merytoryczny}

Czy opisywaną grupę tłumaczy łączyła świadomość przynależności do określonej wspólnoty intelektualnej? Niewątpliwie cechowała ich określona postawa intelektualna polegająca na dążeniu do popularyzacji kultury poprzez przekład dzieł literackich. Wiązała się nią troska o jakość tłumaczenia oraz o aparat krytyczny dostosowany do potrzeb projektowanego odbiorcy: obszerne wstępy, posłowia, noty biograficzne o autorach, przypisy wyjaśniające elementy historyczne i realioznawcze itp. Te podstawowe założenia sztuki przekładowej były jednak wspólne dla większości tłumaczeń literackich publikowanych w tym okresie ${ }^{11}$. Obserwowana przez nas wspólnota tłumaczy jugoslawistów nie wyrażałaby się zatem apriorycznym manifestowaniem odrębności od innych orientacji przekładowych ${ }^{12}$, lecz polegałaby raczej na wspartej świadomością teoretyczną polemice $\mathrm{z}$ przedsięwzięciami translatorskimi podejmowanymi w innych ośrodkach ${ }^{13}$. Wynikiem poszerzonych kompetencji tłumaczy stała się pogłębiona refleksja okołoprzekładowa - w paratekstach towarzyszących ukazującym się przekładom formował się dyskurs traduktologiczny polskiej jugosłowianistyki ${ }^{14}$. Jego tematem była przede wszystkim wspomniana wyżej dyskusja nad konkretnymi rozwiązaniami w prezentowanych tłumaczeniach, ale również ocena wyboru dzieł przedstawianych polskiemu czytelnikowi oraz ogólniejsza refleksja związana z miejscem tłumacza i jego działalności w komunikacji międzykulturowej.

\section{Szczegółowa charakterystyka szkoły}

Zastanawiając się nad czynnikami natury pozafilologicznej, które decydowały o przekładzie literackim w tym okresie, musimy mieć przede wszystkim na uwadze, że wpływ tłumacza na wybór tekstu ograniczony był specyficznymi czynnikami ${ }^{15}$. Przekłady, które wówczas powstawały, stanowiły realizację ustalonych odgórnie oczekiwań. Był to czas, w którym nastąpiła profesjonalizacja

10 Ibid., s. 359-380.

11 Zob. W. Sadkowski, Odpowiednie dać słowu słowo. Zarys dziejów przekładu literackiego $w$ Polsce, Toruń 2013, s. 139.

12 Por. J. Woleński, op. cit., s. 310.

13 Warto znaczyć, że polemiki wewnętrzne toczące się wokół konkretnych rozwiązań nie negują istnienia pewnego centralnego zespołu poglądów łączących grupę, por. ibid., s. 311.

14 Zwłaszcza teksty w „Literaturze na Świecie” dotyczyły bezpośrednio warsztatu tłumacza.

15 L. Małczak, op. cit. s. 48-49. 
współpracy kulturalnej międzypaństwowej, zatem przepływ tekstów między dwiema kulturami regulowały programy wymiany kulturalnej oraz „listy książek do przełożenia", ustalane w tym przypadku przez stronę jugosłowiańską i polską $^{16}$. Profesjonalizacja zawodu thumacza literackiego w Polsce, co podkreśla m.in. W. Sadkowski, skutkowała wzrostem jakości tłumaczeń ${ }^{17}$. Nie należy tracić $\mathrm{z}$ oczu również ówczesnych uwarunkowań odbiorczych, $w$ tym istotnego zjawiska, jakim był fenomen popularności „,iteratury przełożonej” w PRL ${ }^{18}$.

\section{Prekursorzy}

Wniosek, że literacki przekład polsko-chorwacki wyrósł w próżni po roku 1945, napędzany jedynie odgórnym planowaniem kultury i podziałem środków finansowych w powojennej rzeczywistości, byłby oczywiście nietrafny. Opisane wyżej uwarunkowania polityczne, $w$ jakich powstawały przekłady, miały ogromne znaczenie. Jednak obraz nie byłby pełny, gdybyśmy pominęli to, co działo się na terenie przekładu z języka chorwackiego przed II wojną światową. To „Bibliotece Jugosłowiańskiej" polonofila Julija Benešicia, serii wydawanej w latach 19301939 (ukazało się w tym czasie 13 tomów przekładów z literatury chorwackiej, serbskiej i słoweńskiej), zawdzięczamy pierwszy zrealizowany zamiar systematycznego przybliżania literatury tego obszaru polskiemu czytelnikowi. Również ideał thumacza popularyzatora w obrębie związków polsko-chorwackich nawiązuje do działalności przedwojennej Benešicia ${ }^{19}$ - wcielała go w życie m.in. Halina Siennicka, tłumaczka i autorka przewodnika, kontynuująca działalność po wojnie.

\section{Osiąnięcia szkoły}

Ważkość dokonań potencjalnie istniejącej szkoły w zakresie przekładu polsko-chorwackiego nie budzi wątpliwości. Przełożono w tym okresie trzon współczesnej klasyki chorwackiej ${ }^{20}$, wykształcono nową kadrę tłumaczy neofilologów. Wypracowano także metodę przybliżania kultury chorwackiej poprzez „dydaktyczną egzotyzację", na którą składały się zarówno sposób postępowania z kulturemami w tekście docelowym (o czym szerzej w dalszej części tekstu), jak i widoczna w paratekstach komparatystyczna metoda odnoszenia dzieł chorwackich do literatury polskiej (stosowana m.in. przez Jana Wierzbickiego). Sadkowski od-

${ }^{16}$ Zob. ibid., s. 50-59. Z kolei W. Sadkowski w monografii poświęconej dziejom polskiego przekładu literackiego kładzie nacisk raczej na indywidualne przedsięwzięcia tłumaczy dążących do przekazania polskiemu czytelnikowi przekładów poszczególnych dzieł.

17 W. Sadkowski, op. cit., s. 139-140. Jako istotny czynnik wpływający na jakość przekładów autor wskazuje „wysokie w większości umiejętności i kompetencje zawodowe czołówki translatorskiej”.

${ }^{18}$ Ibid., s. 130-131.

${ }^{19}$ Postać J. Benešicia jako wzór thumacza popularyzotora przywoływana była później wielokrotnie, m.in. w kontekście wydania pierwszej zrealizowanej po wojnie antologii Liryka jugosłowiańska, zob. J. Wierzbicki, Pierwsza polska antologia liryki jugostowiańskiej, „Pamiętnik Słowiański” 1962, t. 12, s. 218 .

${ }^{20}$ M.in. dzieła Miroslava Krležy, zob. L. Małczak, op. cit., s. 466. 
notowuje wzrost liczby dyskusji translatologicznych w tym okresie (przeważnie w formie uwag zwartych w recenzjach), a ich specyfikę upatruje w koncentracji na technikach i zabiegach mających doskonalić przenoszenie dzieł obcych na grunt polski ${ }^{21}$. Tendencje te nie ominęły również przekładu z języka chorwackiego i towarzyszących im paratekstów, co uwidaczniają prowadzone wówczas polemiki wewnętrzne i zewnętrzne.

Znacząca wymiana zdań wewnątrz środowiska dotyczyła pierwszego przedsięwzięcia antologicznego, jakim była Liryka jugosłowiańska ${ }^{22}$. Ukazała się ona w 1960 roku pod redakcją Zygmunta Stoberskiego ${ }^{23}$. Jan Wierzbicki, recenzując antologię w tekście zatytułowanym Pierwsza polska antologia liryki jugosłowiań$s_{k i e j}{ }^{24}$, za największy jej atut uznaje udział poetów (Szymborska, Kamieńska, Iłłakowiczówna, Wat, Jastrun, Ficowski... $)^{25}$, jednak zbyt duża liczba tłumaczy i podobna liczba tekstów każdego autora są według recenzenta mankamentem przedsięwzięcia. Jednocześnie Wierzbicki stawia tłumaczeniom konkretne zarzuty, którymi są w jego ocenie „,nieprecyzyjne posługiwanie się słowem” oraz „,niwelująca rola przekładów". Akcentuje zatem dwie - powiedzielibyśmy dzisiejszym językiem traduktologii - dominanty przekładowe, które uznaje za podstawę pozytywnej oceny thumaczenia: ,wierność” tekstowi wyjściowemu, jego zawartości semantycznej, stylistyce, obrazowaniu, oraz ,wierność” autorowi oryginału i kulturze wyjściowej. Recenzent pisze wręcz o ,sprowadzaniu wielu indywidualności twórczych do wspólnego mianownika” oraz „skłonności do sztucznej poetyzacji”, nieobecnej w oryginale, czego efektem jest wypełnienie antologii tekstami znajdującymi się na poziomie epigonów polskiej liryki. Podobny zarzut, naświetlony jednak nieco inaczej, w duchu herderowskim, stawia antologii E. Madany w recenzji Współczesna liryka jugosłowiańska ${ }^{26}$. Przyczyn zbytniej jednorodności stylistycznej tomu Madany dopatruje się w niewyodrębnieniu klimatu poezji poszczególnych grup etnicznych. Recenzje nie pozostały bez echa - jedna z thumaczek tomu, Halina Kalita, odpowiedziała w „Nowej Kulturze” na zarzuty o przypisywaną jej przez Wierzbickiego „mechaniczną dosłowność” ${ }^{27}$. Jak się zatem wydaje, parateksty te traktować możemy jako początek XX-wiecznej dyskusji traduktologicznej nad przekładami z języka chorwackiego. Zatarcie indywidualizmu stylistycznego poszczególnych autorów czy też odmienności kulturowej tekstów traktowane jest tu jako wyznacznik nieudanego przekładu, prezentowana perspektywa zbliża się więc do nowoczesnego spojrzenia na traduktologiczne pojęcie fidélité, wykraczającego poza śledzenie filologicznych potknięć tłumacza ${ }^{28}$.

${ }^{21}$ W. Sadkowski, op. cit., s. 149, 153 .

${ }^{22}$ Spory te relacjonuje wyczerpująco L. Małczak, zob. Małczak, op. cit., s. 230-231.

${ }^{23}$ Liryka jugosłowiańska, wstęp J. Iwaszkiewicz, red. Z. Stoberski, wybór T. Maldenović, N. Simić, D. Szega, Warszawa 1960.

${ }^{24}$ J. Wierzbicki, Pierwsza polska antologia ..., s. 218-220.

${ }^{25}$ Większość tłumaczeń powstawała, jak możemy przypuszczać, na podkładkach filologicznych, jednak J. Wierzbicki nie odnosi się do tego faktu.

${ }^{26}$ E. Madany, Wspótczesna liryka jugostowiańska, „Nowe Książki” 1961, nr 9, s. 538.

${ }^{27}$ H. Kalita, Krytyka - tak, ale rzetelna, „Nowa Kultura” 1963, nr 8, s. 6.

${ }^{28}$ Które, trzeba przyznać, będzie jeszcze przez wiele lat podstawą recenzji, zwłaszcza przekładów liryki. 
Język i sposób argumentacji dojrzewały również w polemikach zewnętrznych, zwłaszcza z nowym opiniotwórczym rywalem, który pojawił się na scenie przekładowej i przekładoznawczej pod koniec lat 70. i w latach 80. Mowa tu o środowisku związanym ze slawistyką krakowską. Jednym przykładów dyskusji towarzyszącej przedsięwzięciu przekładowemu może być reakcja recenzentów na tom Slavka Mihalicia Sen $w$ świetle w wyborze i thumaczeniu Juliana Kornhausera ${ }^{29}$. Wierzbicki pozytywnie ocenia fakt, że ten właśnie chorwacki poeta doczekał się tomiku w języku polskim, natomiast o samych tłumaczeniach wyraża się sceptycznie, pisząc wprost: „Kornhauser [...] o wiele lepiej umie o poezji pisać, niż ją thumaczyć”30. Z kolei Grzegorz Łatuszyński skupia się na wyłapywaniu poszczególnych błędów filologicznych oraz krytykuje wybór tekstów dokonany przez krakowskiego jugoslawistę ${ }^{31}$. Jak się wydaje, o profilu krytyki decydował tu nie tyle fakt, że przekład Kornhausera był istotnie nieudany filologicznie, ile pragmatyczna możliwość skolacjonowania wyboru nieprzekraczającego trzydziestu wierszy z oryginałami. W przypadku obszernej antologii przeprowadzenie tak drobiazgowej analizy nie było wykonalne i nie pokusił się o to żaden $\mathrm{z}$ recenzentów.

Niektóre z przekładów wzbudziły tak duże kontrowersje we wszystkich ośrodkach slawistycznych, że echa tych dyskusji dotarły również do Chorwacji. Tak było w przypadku tomu Balade Petrice Kerempuha Miroslava Krležy, którego thumaczenia podjął się Alija Dukanović3 ${ }^{32}$. Wydane w 1893 roku Ballady Pietrka Kerempuha, bardzo dobrze przyjęte przez środowisko „Literatury na Świecie” (nagroda za najlepszy przekład 1984 roku) ${ }^{33}$, zostały ostro skrytykowane m.in. przez Krystynę Bąk („Czytać się tego nie da. A szkoda”) ${ }^{34}$, sceptycznie odniosła się do tego przekładu również Maria Dąbrowska-Partyka w tekście opublikowanym w chorwackiej „Republice" ${ }^{35}$. Mniej krytyczna była Magdalena Koch, która na łamach „Odry” uznała, że thumacz wyszedł z tego niełatwego zadania przekładowego obronną ręką ${ }^{36}$. Polski tekst Ballad, opatrzony obszernym wstępem, w którym thumacz odnosił się do swojej metody przekładowej, oraz tocząca się wokół niego dyskusja dobrze wpisują się w odbywające się wówczas poszukiwania rozwiązań praktycznych w zakresie przekładu literackiego z języka chorwackiego. Niewątpliwie jednym z zasadniczych problemów, które dostrzeżono i dla których próbowano wypracować rozwiązania w zgodzie z ogólnymi tendencjami w przekładzie literackim, była istotna dla Chorwacji kwestia języków regional-

\footnotetext{
${ }^{29}$ S. Mihalić, Sen w świetle, przeł. J. Kornhauser, Warszawa 1980.

30 J. Wierzbicki, Literatury Jugosławii, ,Rocznik Literacki” 1980, Warszawa, s. 562.

${ }^{31}$ G. Łatuszyński, Uwolnić się od cudzych słów, ,Nowe Książki” 1981, nr 19, s. 21-23.

${ }_{32}$ M. Krleža, Ballade Petrice Kerempuha (1936), wyd. polskie: Ballady Pietrka Kerempuha, przeł. A. Dukanović, Warszawa 1983.

33 J. Wierzbicki, Krleža i „Ballady Pietrka Kerempuha”, „Literatura na Świecie” 1984, nr 8, s. $317-327$.

${ }^{34}$ K. Bąk, Świerzop bursztynowy, „Przegląd Tygodniowy” 1984, nr 10, s. 13.

${ }^{35}$ M. Dąbrowska-Partyka, Kulturni uvjeti prijevoda ili ,zakaj se nemre”. O Baladama Petrice Kerempuha, „Republika” 1983, nr 7-8, s. 34-39.

${ }^{36}$ M. K. [M. Koch], Miroslav Krleža: „Ballady Pietrka Kerempuha”. Przetożyt i wstępem i objaśnieniami opatrzyt Alija Dukanović. PIW. Warszawa 1983, s. 193, „Odra” 1984, nr 7/8, s. 101.
} 
nych w przekładzie. W praktyce przekładowej tego okresu możemy wyraźnie zaobserwować, że problem ten traktowany był jako jedno z zasadniczych wyzwań.

Aby zobrazować sposoby podejścia do problemu językowej charakterystyki gwarowej w przekładach literatury chorwackiej, możemy porównać dwa thumaczenia opowiadań wojennych Miroslava Krležy na język polski: Magyar Kiralyi Honved Novella, przełożone przez Władysława Glücka i Halinę Siennicką ${ }^{37}$, oraz Bitwa pod Bystrzyca Leśna w przekładzie Aliji Dukanovicia ${ }^{38}$. Ich powstanie dzieli około dwudziestu lat, różne jest też podejście tłumaczy do materiału wyjściowego. W pierwszym przekładzie zupełnie brak oznak socjologicznego nacechowania języka bohaterów. Usunięto liczne gwarowe wyrażenia w dialogach i narracji prowadzonej w mowie pozornie zależnej: da je on, kakbirekli; kakbirekli bumorekli; bumorekli; si razmel; kuš; bute vi. Inne zostały oddane w polszczyźnie literackiej lub potocznej: poglečte ga > popatrzcie; ćaća i deda > ojciec i dziadek; jer buš lizal z gubicom tvojom zagoreškom blato na potplatu če mi ne očistiš špice > bo będziesz mi je lizat swym zagórzańskim jęzorem. Również zamieszczone w opowiadaniu fragmenty Biblii w przekładzie kajkawskim oddane zostały w polszczyźnie literackiej. Tłumaczenie z roku 1961 obfituje natomiast w wyrażenia nacechowane dialektalnie oraz - mające pełnić podobną rolę - archaizmy. Dukanović polszczy tekst Krležy językiem potocznym, wplatając słownictwo gwarowe (czy raczej odczuwane jako takie) oraz lekko archaizowane: stvorio je > wyrychtowat; propusti $>$ prześlepi; bolesna i sušičava > z paskudnikiem w oku (krowa). Niekiedy w tekście wyjściowym w tym miejscu znajdują się elementy nienacechowane stylistycznie: u rat > na wojenkę; odnotować należy również wypadek dodania stylizowanego fragmentu: aby nasienie w żywicielce nie wyprzało, aby się kąkolem nie wykłosiło.

\section{Wpływ i znaczenie szkoły}

Znaczenie i wpływ potencjalnej polsko-chorwackiej szkoły przekładowej należy rozpatrywać z kilku punktów widzenia. Niewątpliwie wypracowała i podtrzymywała określony model tłumacza, dla którego najważniejsze były kompetencje językowe i kulturowe, dydaktyczno-popularyzatorskie i historycznoliterackie, a także odpowiedzialność za jakość i wybór tłumaczonych tekstów (nawet jeśli w warunkach odgórnego sterowania kulturą mocno ograniczona). Ten model tłumacza, będącego jednocześnie autorytetem akademickim, praktykiem tłumaczenia, autorem przewodników, pozycji dydaktycznych, inicjatorem i redaktorem przedsięwzięć antologijnych (a nierzadko i dyplomatów), przeminęła - jak się wydaje - wraz z wymianą generacyjną, a jego miejsce zajęła atomizacja ról.

Szkoła miała również zasadniczy wpływ na aspekt czytelniczy i popularyzatorski. Co ciekawe, wydaje się, że nawet w warunkach ograniczenia cenzurą i sterowana rynku indywidualne przedsięwzięcia konkretnych tłumaczy miały ogromny wpływ na tę część piśmiennictwa narodowego. Bardzo wyraźne było

${ }^{37}$ M. Krleža, Chorwacki bóg Mars, przeł. W. Glück i H. Siennicka, Warszawa 1939.

38 Bitwa pod Bystrzyca Leśna, przeł. A. Dukanović [w:] M. Krleža, Świerszcz pod wodospadem, Warszawa 1961. 
to w przypadku małych literatur, w których osobiste preferencje, kontakty zawodowe czy towarzyskie tłumaczy i pisarzy prowadziły do spopularyzowania konkretnych dzieł ${ }^{39}$. Za L. Małczakiem możemy przywołać tu jako przykład fenomen Vladana Desnicy ${ }^{40}$, który stał się najbardziej rozpoznawalnym po Krležy pisarzem chorwackim - ze względu na ilość tłumaczeń oraz poświęconych mu recenzji. Innym prozaikiem hołubionym na polskim rynku wydawniczym był na przykład Krsto Špoljar, którego trzy powieści ukazały się w przekładzie Danuty Cirlić-Straszyńskiej ${ }^{41}$. Z kolei poetą najczęściej drukowanym w latach 60. i 70. był Milivoj Slaviček ${ }^{42}$, a tę popularność wiązać należy w znacznym stopniu ze związkami artysty z Polską: częstymi wizytami i kontaktami osobistymi.

Popularność niektórych pisarzy preferowanych przez ,szkołę przekładową” znalazła swoje odbicie w kształceniu akademickim na neofilologiach, najpierw serbsko-chorwackiej, a potem chorwackiej. Nieuzasadnionym uproszczeniem byłoby stwierdzenie, że spis lektur na filologii uniwersyteckiej formowany był na podstawie dorobku pisarzy chorwackich wydanych w przekładach na język polski. Jednak echa tej „,przekładowej hierarchii”, która ustalała się do lat 80 ., znajdujemy na tym obszarze aż do dziś, o czym świadczy na przykład obecność na listach lektur wspomnianego Krsta Špoljara ${ }^{43}$.

O wiele istotniejszy jest fakt, że to właśnie powstające wówczas tłumaczenia kształtowały ,polszczyznę chorwacką”, czyli język, w którym powstawały nie tylko przekłady dzieł literackich z tego obszaru, ale również wszelkie inne teksty dotyczące Chorwacji i jej kultury. Tłumacze lat 60. i 70. wypracowywali pewne rozwiązania praktyczne, powtarzali je w przekładach poezji i prozy, ale także zawierali w tworzonych przez siebie słownikach, rozmówkach, przewodnikach, wywiadach z pisarzami, recenzjach, omówieniach itp. Rozwiązania praktyczne wprowadzone przez nich (m.in. dotyczące onimów i pozostałych kulturemów)

${ }^{39}$ Znamienne, że W. Sadkowski jako jedynego tłumacza literatury jugosłowiańskiej wymienia Danutę Cirlić-Straszyńską. Opisując w superlatywach warsztat tłumaczki, przypisuje jej ,,strategiczny plan uprzystępnienia naszej kulturze literackiej bogatego pokłosia nowej jugosłowiańskiej twórczości literackiej". Jest to zgodne z prezentowaną przez tego badacza wizją, w której wybitne znaczenie przypisuje się indywidualnościom przekładowym. Zob. W. Sadkowski, op. cit., s. 159.

40 Zob. L. Małczak, op. cit., s. 238-239. Polskie przekłady: V. Desnica, Niespokojne wiosny, przeł. Z. Stoberski, Warszawa 1960; Przed świtem, przeł. Z. Stoberski [w:] Bar Titanic. Jugostowiańskie opowiadania wojenne, wybór i wstęp A. Dukanović, Warszawa 1962, s. 273-284; Zimowe letnisko, przeł. M. Krukowska, Warszawa 1963; Przed świtem, przeł. Z. Stoberski [w:] Antologia noweli jugosłowiańskiej, wybór i wstęp B. Cirlić, Warszawa 1964, s. 596-606; Wiosna w Badrovacu i inne opowiadania, przeł. M. Krukowska, Z. Stoberski, Warszawa 1968.

${ }^{41}$ K. Špoljar, Statek czeka do jutra, przeł. D. Ćirlić-Straszyńska, Warszawa 1973; Kłopoty z muza, przeł. D. Ćirlić-Straszyńska, Łódź 1983; Ślub w Paryżu, przeł. D. Ćirlić-Straszyńska, Warszawa 1990.

42 Obok Vesny Parun, zob. L. Małczak, op. cit.

43 Przykładowo Krsto Špoljar (1930-1977) figuruje w chwili obecnej w spisie lektur dla specjalizacji kroatystycznej w ramach filologii słowiańskiej na Uniwersytecie Jagiellońskim z pozycją Vjenčanje u Parizu. W latach 90. XX wieku obowiązkowe były jego dwie powieści: Brod čeka do sutra oraz Neprilike s muzom. Włączenie do listy lektur tego pisarza (w Chorwacji uznawanego raczej za drugoligowego i nieobecnego choćby w programie nauczania szkół podstawowych i średnich) można wiązać $\mathrm{z}$ dostępnością tych przekładów w polskich bibliotekach, co w erze przedcyfrowej było jednym z głównych czynników decydujących o możliwości dotarcia do danej pozycji. 
stały się naturalnym wyborem dla wszystkich uczestników chorwacko-polskiej komunikacji kulturowej. Nie tylko takich rozwiązań oczekiwano w nowych tekstach pojawiających się w obiegu czytelniczym, ale - jak się wydaje - wywierały one (i wywierają do dziś) wpływ na wybory tłumaczy kroatystów na obszarze przekładu pozaartystycznego.

Specyfika i ewolucja metody przekładowej stanie się wyraźniejsza, jeśli zilustrujemy ją konkretnymi przykładami. Pierwszy z nich dotyczy aplikacji do tekstu docelowego antroponimów fikcyjnych. Porównując przekłady opowiadań Miroslava Krležy dokonane w latach $30 .{ }^{44}$ oraz 60 . i 70. XX wieku ${ }^{45}$, zauważamy wyraźną zmianę, jaka nastąpiła w strategii przekładowej w stosunku do tych elementów tekstu wyjściowego. W starszych tłumaczeniach regułą jest polszczenie imion postaci: Jambrek > Ambrożek, Franjo > Franciszek, Katica > Kasieńka, Ružica i Štefek > Rózia i Stefek. Efektem tego zabiegu jest utrata wskaźnika etnicznego i pozostawienie funkcji identyfikacyjnej jako jedynej. Z kolei przekłady powstałe w omawianym przez nas okresie dążą wyraźnie do tego, aby wskaźnik etniczny zachować, i przenoszą większość imion do tekstu docelowego w postaci niezmienionej: Tomo, Ivan itd. Co ciekawe, w tłumaczeniach nowszych pojawiają się również na tym polu drobne odstępstwa od tej zasady, polegające na wprowadzaniu nieobecnych w oryginale zdrobnień: Henrik $>$ Henryczek, Franjo $>$ Franio, co skutkuje nie tylko likwidacją nacechowania kulturowego, ale także waloryzacją emocjonalną zjawisk świata przedstawionego w stosunku do oryginału.

Strategie te niewątpliwie pozostawały w zbieżności z tendencjami w ogólnopolskim przekładzie literackim ${ }^{46}$, jednak analizując poszczególne rozwiązania przekładowe dotyczące kulturemów chorwackich, dostrzegamy, że jest to etap, na którym pewne rozwiązania są dopiero wypracowywane.

Wyrazistym przykładem prób przyswojenia polszczyźnie chorwackiego kulturemu jest przypadek południowego wiatru jugo/jugovina, którego nazwa często pojawia się w tekstach literackich, m.in. w wyborze opowiadań Miroslava Krležy Tysiąc i jedna śmierć, wydanym w Polsce w 1978 roku ${ }^{47}$. Tłumaczka Irena Olszewska transkrybuje leksem jugovina jako ,jugowina”. Egzotyzm ten, czytelny słowotwórczo i niepowodujący niezręczności gramatycznych, opatrzony zostaje odpowiednim przypisem: ,silny wiatr południowy”. To posunięcie nie ma konsekwencji w dalszych partiach tekstu, pojawi się tam już tylko parafraza „ten gorący wiatr”. Podobnie postępuje Krystyna Bąk, proponując określenia opisowe ,wiatr z południa” oraz nacechowane emocjonalnie ,wietrzysko z południa” i ,południowe wichrzysko”. Analogiczny zabieg możemy odnaleźć w tłumacze-

${ }^{44}$ M. Krleža, Chorwacki bóg...

${ }^{45}$ M. Krleža, Śmierć Toma Bakrana, przeł. H. Kalita [w:] M. Krleža, Świerszcz pod wodospadem, Warszawa 1961; idem, Ivan Križovec, przeł. M. Młynarska [w:] M. Krleža, Tysiąc i jedna śmierć, Warszawa 1978; idem, O miłości Marcela Fabera-Fabriczyego do panny Laury Warronigg, przeł. J. Wierzbicki [w:] M. Krleža, Tysiąc i jedna śmierć, Warszawa 1978.

46 W. Sadkowski, Odpowiednie dać słowu słowo..., s. 113-114.

${ }^{47}$ M. Krleža, In extremis, przeł. I. Olszewska [w:] M. Krleža, Tysiąc i jedna śmierć, Warszawa 1978; Wiatry nad prowincjonalnym miastem, przeł. K. Bąk [w:] M. Krleža, Tysiąc i jedna śmierć, Warszawa 1978; O tym, jak doktor Gregor po raz pierwszy w życiu spotkat Diabła, przeł. M. Głowacka [w:] M. Krleža, Tysiąc i jedna śmierć, Warszawa 1978. 
niu autorstwa Małgorzaty Głowackiej, gdzie jugovina to „południowy wiatr”, a także „wiatr od południa”.

Tę metodę wprowadzania kulturemów chorwackich do tekstu polskiego można określić jako „dydaktyczną egzotyzację”. Jest ona zgodna z popularyzatorsko-dydaktycznym profilem ,szkoły thumaczeniowej”, której celem było przybliżenie chorwackiej kultury polskiemu odbiorcy poprzez objaśnianie i ilustrowanie za pomocą różnych narzędzi: rozwinięć i peryfraz definicyjnych stosowanych w tekście docelowym, lub przez rozmaite rodzaje paratekstów: przypisy, wstępy i posłowia ${ }^{48}$. Unikano zarówno zbyt częstego bezpośredniego transferu elementów nieprzetłumaczalnych ze względów kulturowych, jak i zabiegu ich opuszczania. Ograniczymy się tutaj do jednego przykładu - we fragmencie przełożonego przez Marię Krukowską opowiadania Krležy Świerszcz pod wodospadem pojawiają się potrawy typowe dla północnochorwackiej kuchni: hajdinske žgance s kiselim vrhnjem, pečena purica s mlincima. Pełnią one tu rolę bliską Proustowskiej magdalence, ponieważ były to ulubione dania przyjaciela wspominanego przez narratora-bohatera. Tłumaczka, skądinąd znawczyni kultury i propagatorka kultury jugosłowiańskiej, przekłada te elementy w następujący sposób: ,kasza gryczana ze śmietaną”, , ,pieczona indyczka z blinami". Niektóre rozwiązania wydają się dziś kuriozalne, choć pokazują dobrze, w jakim kierunku podążały strategie thumaczy - na przykład A. Dukanović nadaje obuwiu noszonemu przez chorwackich chłopów (opanke) polską nazwę właściwą konkretnemu elementowi polskiego stroju ludowego: „kierpce”49.

\section{Podsumowanie}

Jak widać z powyższego przeglądu, kilka argumentów przemawia na rzecz istnienia polsko-chorwackiej szkoły przekładowej. Wśród nich znajduje się m.in. argument pragmatyczny: thumacze lat 60 . i 70. byli twórcami nowoczesnej ,,polszczyzny chorwackiej”, dla której charakterystyczne jest m.in. wypracowanie strategii przekładowej odnośnie do kulturemów. Stosowaną metodę określiliśmy jako przybliżanie kultury chorwackiej polskiemu odbiorcy przez „dydaktyczną egzotyzację", i to właśnie ona pozostała na długo najpowszechniejszą techniką stosowaną wobec do tych elementów w thumaczeniu literackim.

Najważniejszą wątpliwością, niepozwalającą zdefiniować omawianej grupy tłumaczy popularyzatorów jako „szkoły przekładowej”, jest moim zdaniem brak dyskursu traduktologicznego wyraźnie odrębnego od tego, który prezentowały w tym okresie pozostałe dyskusje okołotłumaczeniowe w Polsce ${ }^{50}$. Brak również szerszej autorefleksji translatorycznej, która ujawniałaby się w wypowiedziach samych tłumaczy z języka chorwackiego. Z kolei rysujący się wówczas wyraźnie

${ }^{48}$ Używam tu terminologii zaproponowanej przez Teresę Tomaszkiewicz w książce Przekład audiowizualny, Warszawa 2006, s. 158-163.

${ }^{49}$ Bitwa pod Bystrzyca Leśna, przeł. A. Dukanović [w:] M. Krleža, Świerszcz pod wodospadem, Warszawa 1961.

${ }^{50}$ Kroatystyczna refleksja przekładoznawcza w dzisiejszym rozumieniu tego słowa to okres późniejszy (lata 90. XX wieku i początek XXI wieku) i nie sposób mówić o niej bez wkładu, jakie wniosły pozostałe ośrodki filologiczne. 
ideał tłumacza autorytetu (nierzadko również akademickiego) można uznać za typowy dla większości tzw. małych literatur. Równie ryzykowne wydaje się wyodrębnienie strategii swoistych dla przekładu z języka chorwackiego, w odróżnieniu od przekładów z pozostałych literatur Jugosławii: tłumacze jugoslawiści „obsługiwali” bowiem z reguły zarówno obszar chorwacko-, jak i serbskojęzyczny.

Wszystkie zastrzeżenia i uwagi nie podważają jednak przekonania o istotnym wypływie, jaki opisywane tutaj dokonania w dziedzinie przekładu literackiego wywarły na późniejszą praktykę przekładową oraz na ogólny wizerunek Chorwacji i jej kultury w oczach polskiego odbiorcy. Podkreślmy, że wpływ ten dokonywał się nie tyle przez prace teoretyczne, ile przez wielorakie oddziaływanie tekstów przełożonych i popularyzujących na przestrzeni kolejnych dekad.

\section{Bibliografia}

Bąk K., Świerzop bursztynowy, „Przegląd Tygodniowy” 1984, nr 10.

Bitwa pod Bystrzyca Leśna, przeł. A. Dukanović [w:] M. Krleža, Świerszcz pod wodospadem, Warszawa 1961.

Dąbrowska-Partyka M., Kulturni uvjeti prijevoda ili ,zakaj se nemre”. O Baladama Petrice Kerempuha, „Republika” 1983, nr 7-8.

Kalita H., Krytyka - tak, ale rzetelna, „Nowa Kultura” 1963, nr 8.

Kot W., Problemy recepcji literatury chorwackiej w Polsce, „Most” 1991, nr 1-2.

Krleža M., Ballade Petrice Kerempuha (1936), wyd. polskie: Ballady Pietrka Kerempuha, przeł. A. Dukanović, Warszawa 1983.

Krleža M., Chorwacki bóg Mars, przeł. W. Glück i H. Siennicka, Warszawa 1939.

Liryka jugosłowiańska, wstęp J. Iwaszkiewicz, red. Z. Stoberski, wybór T. Maldenović, N. Simić, D. Szega, Warszawa 1960.

Łatuszyński G., Uwolnić się od cudzych słów, „Nowe Książki” 1981, nr 19.

M.K. [M. Koch], Miroslav Krleža: „,Ballady Pietrka Kerempuha”. Przełożyt i wstępem i objaśnieniami opatrzyt Alija Dukanović. PIW. Warszawa 1983, s. 193, „Odra” 1984, nr 7/8.

Madany E., Współczesna liryka jugosłowiańska, „Nowe Książki” 1961, nr 9.

Małczak L., Croatica. Literatura i kultura chorwacka w Polsce 1944-1989, Katowice 2013.

Mihalić S., Sen w świetle, przeł. J. Kornhauser, Warszawa 1980.

Sadkowski W., Odpowiednie dać słowu słowo. Zarys dziejów przekładu literackiego w Polsce, Toruń 2013.

Tomaszkiewicz T., Przekład audiowizualny, Warszawa 2006.

Wierzbicki J., Krleža i „Ballady Pietrka Kerempuha”, „Literatura na Świecie” 1984.

Wierzbicki J., Literatury Jugosławii, ,Rocznik Literacki” 1980, Warszawa.

Wierzbicki J., Pierwsza polska antologia liryki jugosłowiańskiej, „Pamiętnik Słowiański" 1962, t. 12.

Woleński J., Filozoficzna szkoła lwowsko-warszawska, Warszawa 1985. 